\title{
Sergio Caruso. Curiositas as a Passion
}

\section{Sergio Caruso. La curiositas come passione}

\author{
Debora Spini \\ New York University in Florence \\ deb.spini@gmail.com
}

\begin{abstract}
The essay explores the work of Sergio Caruso, whose work moved from theories of justice to citizenship, from the notion of ideology to the role of intellectuals. I will retrace some of the fils rouges of Caruso's production and adopt two main lenses of observation. First, his work will be presented as an example of immanent critique, and secondly, it will be analysed in the light of its more or less explicit normative outcomes.
\end{abstract}

Keywords: Sergio Caruso, immanent critique, philosophy of social sciences, happiness.

Riassunto. Il saggio presenta la figura di Sergio Caruso, che si è mossa su un vasto insieme di tematiche che spaziano dalle teorie della giustizia alla cittadinanza, dal concetto di ideologia al ruolo degli intellettuali. Ci si propone di rintracciare alcuni fils rouges del suo lavoro, da un lato proponendolo come esempio di critica immanente $\mathrm{e}$, dall'altro, mettendone in luce dei suoi esiti più o meno esplicitamente normativi.

Parole chiave: Sergio Caruso, critica immanente, filosofia delle scienze sociali, felicità.

Curiosity is, in the great and generous minds, the first passion and the last. (Samuel Johnson).

The term Curiositas indicates, in its original context, a lively and sustained desire for knowledge. Its origin is to be found in the word cura, meaning care, concern, solicitude. At the twilight of the Classic world, 
Augustine brands Curiositas as the restless interest for vain earthly things. Sergio Caruso was undoubtedly curiosus in the Latin sense of the word. His intellectual figure emerges as remarkably unique and original in a scholarly and academic landscape where specialisation seems to be the dominating trend. Caruso continued to be curiosus: he was interested in and solicitous for a wide range of themes, he worked on a variety of topics and he embraced a wide range of methodological approaches, when most scholars - philosophers included - tend to narrow their research interests to one very specific topic, which absorbs nearly the whole of their intellectual production, and opt to confine themselves within the boundaries of rigidly defined schools. In fact, those who had the privilege of being acquainted with him do not find this at all surprising, as the main features of his scholarly profile perfectly fit the marked traits of his personality, which was open and tolerant, quintessentially alien from any kind of ideological rancour and most of all, moved by an ever renewed curiosity for less travelled roads.

Caruso's work moved from theories of justice to citizenship, from the notion of ideology to the role of intellectuals. He investigated the whole field of social sciences, concentrating on the economy, and maintained a constant interest for all themes related to Jewish thought and more generally to biblical culture. A nucleus of overarching lines of interest sustained and guided the philosophical freedom that was such a dominant trait of his intellectual biography. The first example that comes to mind is doubtlessly the theme of emotion and politics; even though it did not materialise in a specific title, this interest surfaces all throughout his work. This theme resonates with another important thread, his reflections on economics; as will be further discussed in section 3, his critique of the supposedly rational foundations of mercatismo (marketism) stems from his views on subjectivity. Even the biblical and theological background plays a major role in his reflections on economics, as it provides important elements for his critique of capitalism as a new religion.

Even though he had a cluster of favourite authors, Caruso never restricted himself to a canon, and always felt free to select his interlocutors, from whatever ideological or disciplinary field they came. His early acquaintance with the tradition of critical Marxism and a lifetime frequentation of Marx's works accompanies all his productions since his earliest writings, and is still apparent in his later works on economics and happiness. The first generation of the Frankfurt school is a constant presence in his work: the reasons are evident, and relate to Caruso's double identity as philosopher and psychoanalyst, whose importance for his overall scholarly production will be discussed in the next paragraphs. Caruso also reconnected in a common genealogical line the authors coming from 
the tradition of Moral Philosophy and of the Anglo-Saxon Enlightenment, whose distant roots he traced all the way back to Selden's England, and contemporary authors such as Michael Walzer and Amartya Sen. These preferred interlocutors, however, did not prevent Caruso from exploring authors whose political positions and cultural background were quite alien to his, such as Oswald Spengler. ${ }^{1}$

In fact, in his intellectual journey, Caruso adopted an equally wide range of disciplinary approaches; some of his works belong to the field of history of political thought - for example, his work on Adam Smith's Wealth of Nations, and the monumental study La Miglior legge del Reg$n o^{2}$ to this day remains the main comprehensive monograph on John Selden $^{3}$ - whilst others may be labelled as political philosophy, or belong even more distinctively to the field of the philosophy of social sciences. As will be discussed in section 2, the wide palette of disciplinary approaches responds to a well defined research program concerning the epistemological legitimacy of social sciences, present all throughout his production, as well as in his teaching.

This present contribution will retrace some of the fils rouges of Caruso's production, without any claim of being exhaustive. It will adopt two main lenses of observation. First, his work will be presented as an example of immanent critique, and secondly, it will be analysed in light of its more or less explicit normative outcomes.

The paper begins by briefly addressing the epistemological aspect of his production, and proceeds to reconstruct how the different thematic threads compose, in his work, a consistent fabric, which rests ultimately on a very ambitious research program: the quest for some kind of universal form of political agency. It will proceed to highlight the main features of his reflection on economics and capitalism, as well as to analyse the main points of his work on biblical and theological categories. Caruso's views in political theory will be discussed at this point, because his strictly speaking "political" thought is in fact the point of convergence of the many thematic as well as disciplinary threads woven throughout a lifetime of scholarly work. The concluding remarks will highlight how the markedly genealogical and critical approach prevailing in most of Caruso's work does not prevent him from developing a normative horizon, and will try to sketch a few possible lines of development of his philosophical legacy.

\footnotetext{
${ }^{1}$ Caruso, Politica del Destino; Intellettuali e mondi possibili.

${ }^{2}$ Caruso, Miglior legge del Regno.

${ }^{3}$ See also the essay on Treitschke, "Lantisemitismo 'liberale."
} 


\section{Philosopher and psychoanalyst}

Any reflection on Caruso's work must take his double identity of philosopher and psychoanalyst as the necessary point of departure. An indepth analysis of this particular aspect of his work evidently exceeds by far the scope of this present reflection, yet Caruso's philosophical research cannot be fully understood without a reference to the other half of his intellectual profile, however partial and limited. Caruso identified with the Freudian school, and in that field he found the main allies in his endeavour of creating a fertile dialogue among the fields of psychoanalysis, philosophy and social science. To this end, it is extremely important to remark that he specifically cherished the clinical, and even more clearly, scientific vocation of Freudian psychoanalysis, up to the point of exploring the interaction of psychoanalytic therapy with neuroscience and even further with biology and chemistry. ${ }^{4}$ Nonetheless, he was not reluctant in affirming the importance of engaging with the Jungian point of view, demonstrating the same intellectual openness and flexibility he showed in the rest of his work. This attention to Jung, quite interestingly, resurfaces in the framework of his reflection on citizenship as well as in the genealogical reconstruction of Homo oeconomicus, ${ }^{5}$ although of course it does not goes as far as Hillman's interpretation of Jung, but focuses on the most Kantian version.

Caruso considered a closer encounter between psychoanalysis and psychology on the one hand, and political theory, political science, and social philosophy on the other, to be absolutely necessary. ${ }^{6}$ His motivations to engage in this exploration are in some cases quite evident, as they relate to the main leitmotivs of his philosophical work: such is the case of the meaning of "happiness", ${ }^{7}$ as well as of his critique of Utopia. ${ }^{8}$ Caruso looked at the psychological/psychoanalytic cluster of disciplines for help in disentangling the enduring confusion about notions such as self, subject consciousness, and identity, ${ }^{9}$ so widespread in the social sci-

\footnotetext{
${ }^{4} \mathrm{His}$ interest in neurosciences and neurobiology is testified by https://www.sergiocaruso.eu/ wp-content/uploads/2020/08/ISTOLOGIA_CITOLOGIA_BIOCHIMICA_SN.pdf.

${ }^{5}$ Caruso, Homo oeconomicus, 115-116.

${ }^{6}$ His "programma di lavoro" (https://www.sergiocaruso.eu/wp-content/uploads/2020/08/Livelli-della-coscienza-individuale.pdf) demonstrates that Caruso considered this exploration to be far from over.

7 Caruso, "Una comune felicità,", 99-108, http://www.cosmopolisonline.it/articolo. php?numero=I22006\&id=10.

${ }^{8}$ Caruso, "Utopie sane."

${ }^{9}$ Smith, Wealth of Nations, 668. Although this remark was made à propos intersubjective subjectivity, its validity extends far beyond that individual case. For Caruso's interest in matching philosophical and psychoanalytical categories, see: https://www.sergiocaruso.eu/wp-content/ uploads/2020/08/Livelli-della-coscienza-individuale.pdf.
} 
ences, which he considered a necessary preparatory step for any reflection on subjectivity. ${ }^{10}$ Psychology and psychoanalysis throw light on a wide spectrum of the dimensions of politics, beginning with the mythical and symbolical dimension; ${ }^{11}$ their crucial role in confuting the "mercatist ideology"12 and its shallow epistemological foundations will also be discussed below in further detail.

However, pointing to the overall significance of this interdisciplinary dialogue is far more important than compiling a list of its fields of application. Caruso expected psychoanalysis to provide an even more resolutive contribution to the study of the social sciences, that of sustaining his endeavour of finding a connection with the dimension of hard sciences, the extreme horizon encompassing his quest for universal forms of political agency. This expectation was not made as explicit as the previous ones, and yet represents a kind of background for his philosophical research as it concerned his view on ontology of the social sciences. Freudian psychoanalysis, insofar as it maintained its scientific dimension and did not forsake dialogue with neuroscience, could provide such a link. This quest for a connection between human, social and natural sciences did not induce any kind of positivist nostalgia in Caruso, as he was we aware of the dangers ingrained in any automatic translation of hard science paradigms into the field of the social sciences; ${ }^{13}$ on the contrary, he repeatedly emphasized the emancipatory and liberating potential ingrained in psychoanalysis. In his view, as psychoanalytic therapeutic practice was finalised to the achievement of as wide a space of personal autonomy as possible, it constituted one of the few available forms of "education to freedom". ${ }^{14}$ Earlier on, in his interview with Michael Walzer, Caruso had remarked of the similarity between psychoanalysis as a form of interpretation and Walzer's immanent approach to social criticism. ${ }^{15}$

\section{Table talks}

The quest for scientific foundations for the social sciences resonates with Caruso's continuous commitment to providing a solid taxonomy of

\footnotetext{
${ }^{10}$ Caruso, Intellettuali e mondi possibili, 82-130.

${ }^{11}$ The relevance of Bion's theories on group behaviour for social and political science was often remarked upon by Caruso, Dispense.

${ }^{12}$ With the term mercatismo, Caruso indicates the dogmatic faith in the market as the only effective and legitimate form of allocating resources; the suggested English translation is Marketism (Homo oeconomicus, 90, note 4).

${ }^{13}$ Caruso, Intellettuali e mondi possibili, 449.

${ }^{14}$ Caruso, "Una comune felicità."

${ }^{15}$ Caruso, “Michael Walzer," 593-627.
} 
social sciences systematic and to mapping the interconnections among human and social sciences as well as between them and natural sciences. Caruso was convinced that social sciences should not stand in awe of "hard sciences", as they could - and should - achieve their own methodological rigour. Caruso shared Searle's belief in social ontology ${ }^{16}$ To use his own words, society is not a text, ${ }^{17}$ but a "fact". This position constitutes the point of departure for his constant commitment to epistemological and methodological reflection, as well as the motivation for his enduring effort to ground political and social research into the field of hard sciences.

Caruso's refusal to be confined within the boundaries of one disciplinary discourse and vocabulary - his curiositas - did not result in some kind of restless and pointless scholarly wandering. On the contrary, it fuelled a very specific focus of attention: the epistemological status of the social sciences, and the consequent consideration of the epistemological relevance of their interaction and mutual dependency and influence. This meta-theoretical and methodological reflection was overwhelmingly present in his decades-long teaching practice, and has been preserved by Caruso himself in a myriad of charts, graphs and class notes, most of which have been happily included and made available on Caruso's website. In particular, his "Dispense", his notes for his philosophy of social sciences course, acutely edited by Brunella Casalini, are much more than a simple didactic tool, but constitute a very interesting starting point for a more systematic reflection. ${ }^{18}$

For Caruso, Philosophy of Social Sciences (PSS) went further than the traditional epistemology of social sciences to attain the level of a reflexive meta-gnoseology, whose ultimate purpose was to contribute to the quest for pure, a priori forms of social experience; a "pure We" along the lines of the Kantian pure self. ${ }^{19}$ Because of their being "pure", Caruso did not expect these a priori forms to be the immediate focus of investigation for PSS; yet, these universals were enshrined within both the historical as well as the material dimension. Philosophy of Social Science can reconstruct its profile by capturing the "shadow" that it projects on empirical, historically determined social interactions. In this perspective, Caruso represented PSS as a sort of "round table", around which gathered a series of couples, formed by each social science and its corresponding philosophy. ${ }^{20}$

\footnotetext{
${ }^{16}$ Searle, "Social Ontology," 12-29.

${ }^{17}$ Caruso, "Filosofia economica," 5.

${ }^{18}$ Most of these materials are gathered in his website. See in particular: https://www.sergiocaruso.eu/wp-content/uploads/2020/08/Tavola-delle-FUNZIONI-DIEGETICHE.pdf.

${ }^{19}$ Caruso, Dispense, p. 12.

${ }^{20}$ The preliminary list provided included 6 pairs: linguistics/philosophy of language, psychology/philosophy of mind, scientific anthropology (both cultural and physical) and philosophical anthropology, economics/philosophy of economics, sociology/ social philosophy, and, last but
} 
Many table talks could thus take place, concerning a wide range of topics, such as the respective categories and lexica, research directions, as well as implicit and explicit value assumptions. ${ }^{21}$

The unlimited freedom that made these conversations around the table possible was far from being incompatible with methodological and lexical rigour; on the contrary, in Caruso's view, it was an essential contribution to a more comprehensive and exact cartography of the specific field of each social and human science, and of their mutual interaction.

\section{Capitalist happiness}

As a philosopher of social sciences, Caruso found many opportunities of engaging with economics and economic theory in his epistemological work. Caruso forcefully claimed economics' place was within the field of social and human sciences, and never among hard sciences; it did not study any "natural" phenomenon, as economic interactions are quintessentially social. Equally forcefully he affirmed the legitimacy of a philosophy of economics, ${ }^{22}$ and of the dialogue between ethics and economics. ${ }^{23}$ It does not come as a surprise to see how all his production is in fact punctuated by essays and book chapters whose subject concerns more or less directly the economic field, ${ }^{24}$ a long string of scholarship leading to the culminating points of his philosophical inquiry on Homo oeconomicus. ${ }^{25}$

Caruso applied his diverse disciplinary skills and approaches to the study of economic phenomena. In this exploration his background as an historian of political thought plays a major role, as well as his life-long frequentation with the tradition of English and Scottish moral philosophy in the sixteenth and seventeenth centuries, where he found a reflexive, inductive and non-deontological approach to ethics particularly congenial to his philosophical program. ${ }^{26}$ Caruso was therefore extremely well equipped

surely not least, political science/political philosophy. Caruso also discussed his conception of social philosophy in "Della felicità."

${ }^{21}$ Caruso, "Mondo," 3.

${ }^{22}$ Elsewhere ("Willy Coyote"; Homo oeconomicus, 3) Caruso declared his interest in economics psychology.

${ }^{23}$ Caruso, "Mondo," 7.

${ }^{24}$ The publications list for the time range 1974-2002 was provided by Caruso himself in a footnote in Caruso, "Amilcare Puviani," 249-255: "Saggio di Hume," 9-64; "Saggi politici di Hume," 105-121; "Platone e il denaro;" Dibattito sull'usura, 563-573; "Amartya Sen," 58-86; "La felicità pubblica?" 72-74.

${ }^{25}$ Caruso, Homo oeconomicus; "Una comune felicità."

${ }^{26}$ Within this general framework, the importance of his encounter with Smith can hardly be overstated. As early as 1973 Caruso participated in the translation and editing of The Wealth of 
to proceed, as per his well-established custom to clear the way of many historical and terminological misconceptions, perfectly exemplified by his genealogical work on Homo oeconomicus. ${ }^{27}$ On the other hand, his "metagnoseological" work on epistemological claims provided him with a set of sharp tools to proceed towards a fully fledged critique of capitalism, which Caruso pitches mostly on the level of subjectivity and of an "integrated" anthropology, which takes psychology in due consideration. Caruso thus conducts a sort of pincer movement encircling the a-critical assumptions and representations of "human nature" as well as the distorted notion of rationality that provided the ground for what he defines as marketist ideology; the next move was that of fighting cheap Darwinism on its own ground, opposing its claims to "scientificity".

The economic crisis has shown that the most individualistic, selfish (marketist) version of Homo oeconomicus was only a statue with clay feet. Gekko is not rational; on the contrary, he is absolutely crazy. ${ }^{28}$ Caruso therefore focused his critique on a shallow notion of rationality exclusively tied to self-interest in the name of a richer philosophical anthropology, which takes into consideration a wider range of motivations as well as empirically-based conceptual models: in this perspective, assuming the existence of a completely rational qua selfish subject is not "scientific", not "realistic" and surely not "anti-utopian": on the contrary, it is one among the many marketist dogmas, to be believed rather than demonstrated. Caruso pointed out how the exclusion of social psychology from economists' view of the subject continues to be a source of misunderstandings, ${ }^{29}$ as psychology and psychoanalysis provide ample empirical evidence of the role of "non-rational" motivations, first of all by expectations. ${ }^{30}$ The reference to psychology helps Caruso push his critique even further, to question the supposedly "scientific" character of marketist views. Because of its

Nations (1973). For the second edition he wrote a note entitled Le parole di Smith, which, far from being a mere translator's note, has the weight of a proper philosophical essay, addressing themes such as self-improvement, self-love or selfishness and most of all sympathy (Wealth of Nations, 28-34). Smith's presence is quite conspicuous in the essay Alla ricerca di una filosofia economica (2007) to naturally culminate in Caruso's work on Homo oeconomicus in 2012 as well as on other essays on Homo oeconomicus as a theological figure ("Homo oeconomicus"). Caruso's Smith is quintessentially "non-Hobbesian". In fact, Caruso considered the so-called "Adam Smith problem" as merely the result of a shallow, reductionist view (Homo oeconomicus, 7; "Homo oeconomicus," 96-97) which did not take into consideration aspects of Smith such as prudence, justice and sympathy.

${ }^{27}$ Caruso identifies all possible versions of Homo oeconomicus, and elaborates an exhaustive taxonomy (Homo oeconomicus, 34).

${ }^{28}$ Caruso, "Willy Coyote," 10.

${ }^{29}$ Caruso, Homo oeconomicus, 31.

${ }^{30}$ Caruso, "Willy Coyote," 7. 
connection with neuroscience, psychology is capable of providing a link with the dimension of "nature", and is the one discipline that may have a claim to the scientific "hardness" so dear to supporters of marketism. Actually social psychology confutes the assumption of an exclusively selfish subject, as it provides abundant evidence in favour of the strong reciprocity hypothesis. ${ }^{31}$

Caruso's identity as a political philosopher as well as a scholar of "moral philosophy" explains the important role played in his economic reflections by the notion of happiness. ${ }^{32}$ His reflections stem from observing the ongoing process of the commodification of happiness typical of capitalist society, which he defined as "the market of happiness". ${ }^{33}$ Reflecting on happiness implies the reassessment of the nature of "desires" and "needs", both of which are, for Caruso, profoundly influenced by the social context of capitalism. Caruso also considered with great attention the possibility of an "economics of happiness". In this field he saw a role not only for philosophy but also for psychology and psychoanalysis, as these disciplines could in fact shed light on the nature and quality of needs and desires. Consequently, any attempt to establish an economics of happiness had to take seriously the empirical evidences proposed by social psychology, so as to avoid becoming mere wishful thinking as in the case of the marketist celebration of "rationality".

This reflection itinerary naturally led Caruso towards the work of Amartya Sen, another of the most important interlocutors in his scholarly production. Caruso follows Sen's footsteps in differentiating between welfare and wellbeing, finding the latter to be much richer and exhaustive than the former for its capacity to include non-material elements, thus performing the extremely important function of reconciling the quest for the good and that for the fair. However, Caruso was aware of the possible risk, engrained in any reflection on the "good life", of sliding into some kind of substantive, naively Aristotelian definition of what happiness should be. At the same time, Caruso found - again with Sen - that the best antidote could only be found in democratic politics. Only a democratic institutional framework in fact allows for the development of a network of conversations and negotiations among individuals about needs, desires and values leading towards the creation of unique life projects.

\footnotetext{
${ }^{31}$ Caruso, Homo oeconomicus, 104.

${ }^{32}$ Caruso, "Comune felicità."

${ }^{33}$ Caruso, Intellettuali e mondi possibili, 9; "Comune felicità," 4.
} 


\section{Judaica and Theologica}

The constant attention to biblical and theological issues constitutes a marked feature of Caruso's production and plays a crucial role in many aspects of his philosophical work. By interacting with psychoanalytic categories, it created an especially sophisticated prism to analyse social and political phenomena. ${ }^{34}$ The transition from Caruso's reflection on economic phenomena and the biblical and theological aspects of his work may appear quite abrupt, yet it is not as brusque as it looks. Caruso's view of modern politics is indeed framed by theological categories and he did share Schmitt's thesis about the debt of all modern political categories to theology. The acknowledgement of the theological origin of political categories is a crucial point of observation for Caruso's reflection on democracy.

On the one hand, it permits the early diagnosis of the processes of the sacralisation of politics and of the rise of political religions which he identified as major pathologies of modern politics, closely connected to the rise of totalitarianism. The sacralisation of politics does not indicate the permanence of religion in the public sphere; quite the opposite, it indicates the deification of political ideas. ${ }^{35}$ The market can also be "sacralised": "the wannabe Smithians of today advocate for - or better: preach - a wild market with no rules. And upon that give battle with the same ardour and fury as in religion wars, as though defending a faith, and a dogma, that nobody is allowed to question: extra mercatum nulla salus". ${ }^{36}$ The insider's knowledge of theology allows Caruso to detect the religious and cultic element in capitalism. On the other hand, the theological horizon helps to put in focus the Utopian dimension, which constitutes, for Caruso, the very ground where democracy is rooted. ${ }^{37}$ Following the wellknown line of interpretation that goes from Buber to Koselleck, Caruso sees in the permanence of a Utopian horizon within modernity a secularised form of eschatology, and he seems to incline towards Voegelin in tracing a special connection between political messianism and the gnostic source. ${ }^{38}$ Such an explicit affirmation of considering the permanence

\footnotetext{
${ }^{34}$ It surely played a major role in his interest in Michael Walzer (Caruso, "Michael Walzer"), as well as in his diverse production on anti-Semitism (Intellettuali e mondi possibili, 484-496). This specific background in biblical culture also led him to investigate the less known sides of some of his key reference authors, as in the case of Spengler's apocalyptic attitude, or Selden's theological background.

${ }^{35}$ Caruso, "Messianismi politici," 6. Caruso indicates Spengler as a typical example of political religion ibid., 7). For an extensive discussion of Spengler see Caruso, Politica del Destino and Intellettuali e mondi possibili, 383-434.

${ }^{36}$ Caruso, "Homo oeconomicus," 27.

${ }^{37}$ Caruso, Intellettuali e mondi possibili, 9.

${ }^{38}$ Caruso, "Messianismi politici," 11.
} 
of a Utopian horizon as an absolutely vital condition for the survival of democracy may sound a bit surprising in an author otherwise so alien from any kind of radicalism. Yet, Caruso, with Mannheim, appreciates the dialectic relationship between utopia and ideology, ${ }^{39}$ as well as the difference between what is utopian and what is utopistic. On this point, he follows Marcuse's steps - at least up to a point - in identifying the first with a transformation which is impossible only in a given historical condition, and the latter with a political project that simply does refuses to take feasibility into consideration. ${ }^{40}$ Caruso also highlights the different relationship to the human and social sciences. Whilst the genuinely utopian projects accept the critique of human sciences, the utopistic approach makes use of the reference to human sciences such as psychoanalysis and anthropology to construct utopia. ${ }^{41}$

With his typical concern for lexical precision, Caruso carefully singles out different elements within the eschatological perspective, differentiating between chiliasm, millenarianism, apocalyptics and messianism. ${ }^{42}$ The differentiation between the messianic and the apocalyptic element that Caruso gets from Martin Buber ${ }^{43}$ is indeed particularly important to understanding the role of Utopian thinking in the democratic horizon as well as to capturing the difference between genuine messianism and political religions. The latter (apocalyptic) is essentially prescriptive; insofar as it is a "revelation", the apocalyptic scenario has already been determined in all its details. Caruso is especially interested in the contradictory legacy of messianism. Typical of political religions is a "fake" version: the false Messiahs are those who turn the promise of universal redemption into that of "expelling evil, all evil, from human life. And not in the Kingdom of Heavens, but here and now, in their kingdom, with political means." ${ }^{44}$ The genuine messianic faith instead believes "in the possibility of the novum within history", but does not claim to own it exclusively and completely. Caruso looks back to the flower of Jewish philosophy, such as Scholem and Benjamin, and even back to their roots in Chassidism, to find the basic criterion to differentiate between "bad" and "good" messianism, or in other words, between the messianism of political religions and totalitarianism and of the messianism that on the contrary, sustains democratic politics: genuine messianism which invokes and does

\footnotetext{
${ }^{39}$ Caruso, La politica del Destino, 8.

${ }^{40}$ Just as he was ready to unmask the fake theology of Homo oeconomicus, Caruso remained sceptical towards any scenario of decrescita felice which he deemed as utopistic.

${ }^{41}$ Caruso, "Utopie sane," 12.

${ }^{42}$ Caruso, "Messianismi politici," 8-10.

${ }^{43}$ Ibid., 12.

${ }^{44}$ Ibid., 10, emphasis in the original, translation mine.
} 
not evoke the Messiah. ${ }^{45}$ Preserving the theological power and uniqueness of Messianism becomes the key to deflating the attempts to construct political religions. Far from originating a prescriptive determinism, Messianism thus keeps the horizon of politics open - to the unexpected, the unpredictable, and most of all to the possible. We shall shortly see how the horizon of possibility defines, for Caruso, the scope of action of political agency.

\section{Last but not least - a political philosophy of citizenship}

As mentioned in the introduction, it can be quite surprising that in these pages Caruso's strictly speaking "political" theory is confined to the last couple of paragraphs. Hopefully, the overall flow of these few lines reconstructing Caruso's work should have demonstrated the reasons for such an unusual choice.

The last book published by Caruso, Per una nuova filosofia della Cittadinanza (For a new philosophy of citizenship), ${ }^{46}$ originating from a lectio magistralis in 2014, provides a stepping stone to touch upon other aspects of his work. Again, Caruso begins this book in his best tradition, by a rich historical lexical dissection of the term, which will be left in the background to the advantage of his more personal thoughts on the future of citizenship.

Caruso was well aware of the momentous challenges faced by democratic citizenship; globalization for him was not a curse, but an unalterable condition which imposed a thorough reconsideration of many of the well established categories of modern politics. ${ }^{47} \mathrm{He}$ pursues a sort of double strategy: on the one hand, he "unpacks" the many elements of democratic citizenship, and on the other, he moves away from the forms of democratic representation which were typical of political modernity.

Caruso has no doubt in affirming the need to replace the vertical structures of the nation state by a more complex multilevel institutional architecture, combining the sub-, super- and infra- state levels. He goes even further, declaring that democracy itself must be critically re-assessed, as the traditional form of "political democracy, based upon multiple parties competing by way of election with universal suffrage, is in fact only one of the possible games that representative democracy can play." ${ }^{\text {48 }}$ Nor is the institutional level of politics the only space where citizenship can

\footnotetext{
${ }^{45}$ Ibid., 16.

${ }^{46}$ Caruso, Per una nuova filosofia.

${ }^{47}$ Caruso, "Mondo."

${ }^{48}$ Caruso, "Comune felicità," 56, translation mine.
} 
be actively performed; in his book Caruso discusses extensively how other forms of citizenship exist - or should exist - alongside the specifically political one. Citizenship thus stretches both vertically and horizontally. The vertical expansion aims at realising institutional forms that may go beyond that of the Nation State; the horizontal direction instead represents the expansion of citizenship from the domain of politics to that of society in general. Caruso follows Bobbio and Dahrendorf in evoking the disappointed promise of democracy, that of democratising society. Yet instead of throwing in the towel, he re-launches the challenge, connecting to this proposal of a multilevel citizenship. To paraphrase the title of a book that was so dear to him, Caruso defines here a series of "Spheres of Citizenship", or in his own words, he deconstructs citizenship as a "bundle of functions", to be exercised in a plurality of arenas, with specific rules of the game in each case. Different forms of agency will thus give life to different forms of autonomy. Civil society is evidently a crucial ground as it is the dimension where individuals engage in all those intermediate associations "constituting the spheres of life of real people, in their flesh and bones, families, firms, churches, local communities, all kinds of associations, and of the discussions taking place within and among them." ${ }^{39}$ Diluting citizenship in civil society also allows us to avoid the impasse caused by the Schmittian political-theological heritage ingrained in notions such as "people" and "popular sovereignty". In light of the genealogical work of the first part of the book, Caruso is ready to conclude that the popolo is probably only a fiction, and in any case a macro-subject which can never find appropriate representation. ${ }^{50}$ Popular sovereignty must be reformulated in terms of "a variable-geometry collective force", which can freely re-organise itself in the sphere of civil society. ${ }^{51}$ The wager of the democratisation of society has to overcome one major obstacle: the overwhelming power of economic forces. The solution indicated by Caruso is quite radical: citizenship is here reformulated as a subject (more or less in the same terms as the "class") whose antagonists are the "giants", as Colin Crouch defines economic actors. ${ }^{52}$ In more concrete terms, Caruso calls for the horizontal extension of citizenship through the democratisation of each and every one of its spheres.

The re-thinking of citizenship as a "subject" evidently does not mean replacing one anthropomorphic conception with another. Insofar as citizenship is reformulated as a "bundle of functions" performed in a plural-

\footnotetext{
${ }^{49}$ Caruso, "Società civile," 4, translation mine.

${ }^{50}$ Caruso, "Comune felicità," 56.

${ }^{51}$ Caruso, "Comune felicità," 70.

${ }^{52}$ Crouch, Strange Non-Death.
} 
ity of levels and arenas, so is the identity of the "citizen": the "citizen" that Caruso has in mind is essentially the crossroads of a series of relationships and interactions. Caruso's reflection on citizenship thus encounters the theme of subjectivity; he is, not surprisingly, inclined towards a dialogical, intersubjective model of self. ${ }^{53}$ The political and the philosophical dimensions cannot be separated. With Sen, Caruso is convinced that only within the framework of democracy may individuals be able to engage in conversations concerning not only interests but also values and "passions"; with Taylor and Walzer, Caruso points out how respect and recognition are in fact social goods which should be reallocated in society according to specific criteria of Justice, which may be guaranteed only within a democratic framework.

The psychosociological approach to citizenship leads Caruso to engage with the crisis of democracy at a much deeper level, that of motivation. Democracy suffers, Caruso observes, from the lack of a "political symbology" in a time when the old categories of the $20^{\text {th }}$ century are fading away; therefore, democracy needs to be sustained by a new "political symbology" (simbolica politica) "images capable of transmitting leading ideas" (idee forza) and to be a barrier against the "desertification of politics." 54

\section{By way of conclusion: critique and normativity}

The previous paragraphs have attempted to sketch the patterns formed by the different yet deeply connected threads of Sergio Caruso's research. By way of conclusion, these final lines will try to highlight possible future directions of research. The list of the possible lines of development of Caruso's work could be extremely long, given the breadth and diversity of Caruso's interests. Some of them are implicitly suggested by his peculiar approach to scholarship, evident in each segment of his production. The carefully drawn taxonomies, the models, the charts and the tables testify to his effort to provide a comprehensive systematisation; the punctilious genealogical work is not a show of erudition but a necessary preparation in view of the actual theoretical work. His constant and humble dedication to sharpening the tools for theory remains part of his legacy, and definitely an example to follow.

Some lines of future development were instead explicitly indicated by Caruso himself. His website provides ample evidence of his intention to continue the project of connecting psychoanalysis with, on the one hand,

\footnotetext{
${ }^{53}$ On this point: Caruso, Intellettuali e mondi possibili, 11-130.

${ }^{54}$ Caruso, "Homo oeconomicus," 9.
} 
other "harder" disciplines, such as biology and neuroscience, and even chemistry, and on the other hand, with philosophy of mind. ${ }^{55}$ This gaunt note brings to the forefront of attention a more specifically philosophical task. Caruso's research program causes us to reflect on the relationship between "consciousness" - that for so much of Western philosophy is the alpha and omega of the Subject - and the material, corporeal dimension. This aspect of his reflection could fruitfully be put in dialogue with other philosophical traditions and languages; to make but one suggestion, the galaxy of feminist thought. As is well known, one important legacy of feminist philosophy is the refusal of the mind/body dualism, as well as of a view of the Subject that would not ignore the dimension of the body. This encounter could be especially interesting, first of all because of the important debates which are now taking place within the field of gender theory exactly on the intersection between the construction of the self and the body. Furthermore, the emphasis on the lato sensu "natural" dimension of human existence seems to be a particularly fertile line of work in light of the current, ever worsening, environmental crisis, when humanity is called to reconsider itself as a part of the environment rather than as its predator.

The relevance of his views on the future of citizenship is quite apparent even from the skeletal review presented above, as they resonate with the most recent scholarship on the future of democracy and transnational governance. Per una filosofia della cittadinanza is part and parcel of the quest for new and innovative institutional architectures for a post-national democracy, and shares with a well-established scholarship on transnational democracy the project of moving beyond an anthropomorphic conception of people to embrace multiple demoi as sources of legitimacy. ${ }^{56}$ Even the theological-political reflection is coming into play in view of a very concrete challenge now faced by most contemporary democracies, that of populism. Populist parties and movements do not only thrive off the manipulation of religious symbols and vocabulary; with their promise of purity, they perfectly match the profile of fake Messianism as reconstructed by Caruso. Singling out the fake versions of Messianism, Apocalyptic and Millenarianism, is a most urgent, yet rarely undertaken, line of research in the otherwise crowded field of populism studies.

These examples have no ambition of being exhaustive; more and more themes could be mentioned. However, the essence of his intellectual legacy can be summarised and contained within one of his most constant con-

\footnotetext{
${ }^{55}$ https://www.sergiocaruso.eu/materiali-psicologia-psicoanalisi/.

${ }^{56}$ Nikolaidis, "Idea of European Democracy"; Innerarity, Democracy in European Union.
} 
cerns and interests, that of the role of the intellectual, a sort of meeting ground between his critical and normative perspective. ${ }^{57}$

Not surprisingly, Caruso expects intellectuals to be a critical voice, and to bring to light the pathologies, the contradictions, and the disappointed hopes of democratic societies. ${ }^{58}$ Besides and beyond this pars destruens, Caruso assigns a further responsibility, that of helping social and political actors think about "possible worlds". The theme of Utopia resurfaces with renewed relevance, as in the case of democracy the critical and the Utopian elements must never part ways. Democracy is by its own nature always "incomplete"; and it is vital exactly because it is a work always in progress and never "completed", always aiming to go "beyond" what already exists. When recommending to act at the level of "profound motivations", as mentioned just above, Caruso meant to find a response to the crisis of the utopian tension and to the weakening of its "ideal substance", which he identified as one of the major challenges facing democratic politics today. Intellectuals are therefore in charge of a very special task, that of making it possible to think of the future itself, by introducing within political conversation "a more complex temporality than mere chronology". Philosophers in particular must be sensitive to special "moments": the kairòs which opens an unrepeatable "window of opportunity" for political agency. ${ }^{59}$ Renderci capaci di pensare: making us capable of thinking, again, before it is too late. So apparently humble, yet vast and complex, is the work that Caruso saw as the future of philosophy; to this work, he dedicated a lifetime of intellectual and civic activity. The ample, polyedric, articulated scholarly production that he left behind constitutes a rich reservoir of tools to complete the task he set for our discipline. But an even more precious legacy is to be found in the exemplum that his memory preserves, that of being always ready to engage with new intellectual challenges: curiosity, the first and last passion of great minds.

\footnotetext{
${ }^{57}$ This theme accompanies Caruso all along his intellectual itinerary, from the early essays collected in Intellettuali e $i$ mondi possibili of 1989, through the essay on Amartya Sen's political philosophy of 2002, to reach a kind of culminating point in his 2013 essay whose title (Intellettuale e mondi possibili) significantly echoes that of 1989. Even his essay on Selden could be read in this key, as Caruso studied Selden as an intellectual avant la lettre, and defines him as an "opinion maker" capable of being in dialogue with the "opinion leaders" of his time (Miglior legge del Regno, 836).

${ }^{58}$ The debt with Walzer's view of immanent critique has already been mentioned, but also quite equal is the importance assigned to Social Philosophy (as defined by Honnett) as a form of critique of social pathologies. also engaged with Rahel Jaeggi's critique of forms of life (Jaeggi, Vita e capitalismo). He appreciated her philosophical critical project for its being at the same time radical and reasonable; in her critique of forms of life Caruso recognised an attempt to "raise the stake" of critique, so as to learn from historically determined practices in order to find new solutions as well as to re-formulate judgements.

${ }^{59}$ Caruso, "Intellettuali e mondi possibili," 9.
} 


\section{Acknowledgements}

The author wishes to thank professor Sandro Landucci (Università di Firenze) for his precious comments and suggestions.

\section{References}

Works by Sergio Caruso:

La politica del Destino. Irrazionalismo politico e relativismo storico nel pensiero di Oswald Spengler. Firenze: Cultura, 1979.

Intellettuali e mondi possibili. Itinerari e problemi del pensiero politico moderno e contemporaneo. Firenze: CUSL 1989.

"Lantisemitismo 'liberale' di Heinrich von Treitschke." In Francesca Sofia e Mario Toscano, eds. Stato nazionale ed emancipazione ebraica. 171-213. Roma: Bonacci,1992.

"Michael Walzer, teoria politica e critica sociale. Intervista biograficofilosofica." Iride, 7, 13, (1994): 593-627.

The Wealth of Nations; An Inquiry into the Nature and Causes of the Wealth of Nations. Translated by Francesco Bartoli, Cristiano Camporesi and Sergio Caruso. Milano: ISEDI 1973; Roma: Newton Compton, 1995.

"Utopie sane, utopie malate. Sul fantasticare, fra immaginazione produttiva e regressione difensiva." In Maurizio Regosa, ed. Cinema psicoanalisi utopia. Cremona: Fantigrafica, 1998

La miglior legge del Regno. Consuetudine, diritto naturale e contratto nel pensiero e nell'epoca di John Selden (1584-1654). tomo I:1-432); tomo II:433-1024); con 4 tav. f.t. Milano: Giuffrè, 2001.

"Amartya Sen: la speranza di un mondo 'migliorabile." Testimonianze, XLV, 423, 3 (2002): 58-86.

"Messianismi politici". In Gabriele Boccaccini, ed. Il Messia fra Memoria e Attesa. Brescia: Morcelliana, 2005.

"Alla ricerca della filosofia economica." Testimonianze, LI, 463, 1 (2005): 59-67.

"Mondo". In Parole del mondo globale. Percorsi politici ed economici nella globalizzazione: 111-135. Edited by Andrea Giuntini, Piero Meucci e Debora Spini. Pisa: ETS, 2007.

"Alla ricerca della filosofia economica." Storia del pensiero economico, IV, 2, (2007): 149-186.

“'Società civile': una idea vecchia per un mondo nuovo." Iride, XXI, 52, (2008): 461-471. DOI: https://doi.org/10.1414/26690 
"Willy Coyote gioca in borsa, La crisi economica ripensata da uno psicologo con un po' di filosofia e un pizzico di cinema." Testimonianze, LI, 463, 1 (2009): 59-67.

Homo oeconomicus. Paradigma, critiche, revisioni. Firenze: Firenze University Press, 2012.

"Homo oeconomicus: a false Redeemer. A lecture on today's economic theology (with special regard to the Homo oeconomicus's Birth, Life, Passion, Death, and possible Transfiguration)." Unpublished, 2013. Available at http://www.sergiocaruso.eu/wp-content/uploads/2015/01/Homooeconomicus-a-false-Redeemer-Caruso.pdf. 2013.

“Mondo." In Andrea Giuntini, Piero Meucci, Debora Spini, eds. Parole del mondo globale. Percorsi politici ed economici nella globalizzazione, 11135. Pisa: ETS, 2007.

"L'intellettuale e i mondi possibili." Cosmopolis, IX, 2 (2013). https://www. cosmopolisonline.it/articolo.php?numero $=I X 22013 \& i d=4$.

"Della felicità, tra filosofia e psicologia." In Cecilia Corsi, ed. Felicità e benessere. Una ricognizione critica. 3-54. Firenze: Firenze University Press 2015.

Dispense. Unpublished, 2020. Available at https://www.sergiocaruso.eu/wpcontent/uploads/2020/07/DISPENSE-Caruso-FdSS.pdf.

Other Authors:

Innerarity, Daniel. Democracy in the European Union, A Political Philosophy of the EU. London: Palgrave, 2018.

Nikolaidis, Kalypsos. "The Idea of European Demoicracy." In Julie Dickson and Pavlos Eleftheriadis, eds. Philosophical Foundations of European Union Law. Oxford: Oxford University Press, 2012. https://doi. org/10.1093/acprof:oso/9780199588770.001.0001

Jaeggi, Rahel. Forme di vita e capitalismo. Introduction by M. Solinas. Milano: Rosenberg and Sellier, 2017.

Searle, John R. "Social Ontology Some Basic Principles." Anthropological Theory, 6, 4 (2006): 12-29. https://doi.org/10.1177/1463499606061731. 